\title{
Biochemical and Histopathological studies on female and male Wistar rats fed on genetically modified soybean meals (Roundup Ready)
}

Marwa Ibrahim Eissa ${ }^{1}$, Mohammed Ahmed El-Sherbiny ${ }^{1 *}$, Ayman Maher Ibrahim², Ahmed Abdelsadik Mona Mostafa Mohamed ${ }^{2}$ and Medhat Salah El-Halawany²

\begin{abstract}
Background: Roundup Ready became the most cultivated genetically modified (GM) crop in the world. The aim of this study was to evaluate the effects of a diet containing GM soybean meal (RUR) on male and female Wistar rats. The body weights, food consumption, hematology, serum biochemistry, organ weight, and histopathological examination were compared between rats fed on GM soybean and those fed non-GM soybean after consumption of test diets for 18 weeks.

Methods: Sixty weaned Wistar albino rats (30 females and 30 males) were randomly assigned to three groups of ten rats for each group per each sex. All rats have been fed either a diet containing 0\% GM soybean meal (control), 50\% GM soybean meal (T1), and 100\% GM soybean (T2). The body weights, food consumption, hematology, serum biochemistry, organ weight, and histopathological examination were compared between rats fed GM soybean and those fed non-GM Soybean after consumption of test diets for 18 weeks.

Results: Examined hematological parameters did not indicate a statistically significant difference between the GM soybean-fed groups (T1 and T2) and their respective controls, though the WBCs of the male of treated groups (T1 and T2), platelets count, and hemoglobin (HB) of the female of (T1) group were slightly elevated. The examined biochemical blood parameters showed that the level of triglycerides (TG) was statistically significantly higher in the female treated groups (T1 and T2) and lactate dehydrogenase (LDH) was significantly higher in treated groups compared to their respective controls. Elevated levels of alkaline phosphatase (ALP), aspartate aminotransferase (AST), alanine aminotransferase (ALT), and creatinine were observed in some of the treated groups.

Histopathological examination of selected organs (liver, kidney, and pancreas) and testes or ovaries and female mammary gland revealed histological alterations among different treated groups ( $\mathrm{T} 1$ and $\mathrm{T} 2$ ) with their respective controls.
\end{abstract}

Conclusion: The obtained results indicate the necessity to revise the safety standards of consumption of diets containing GM soybean.

Keywords: Genetically modified soy, Roundup Ready, GM, RUR, Glyphosate

\footnotetext{
* Correspondence: elsherbinymoh@yahoo.com

${ }^{1}$ Regional Center for Food \& Feed (RCFF), 9 El Gamaa Street, Giza, Egypt

Full list of author information is available at the end of the article
} 


\section{Background}

Genetically modified (GM) plants are being widely used in the farm industry. GM crops were introduced to the market in the mid 1990s. Currently, there are over 200 different GM crops with various traits approved for consumption in many countries (Zdziarski, Edwards, Carman, \& Haynes, 2014). Substantial equivalence of GM plants to exist nonmodified crops is one of the keys to accept the use of GM (Haryu, Taguchi, Itakura, Mikami, Miura, Saeki, \& Nakajima, 2009). It has been established that risks to human and animal health from the use of GM crops are negligible (AOAC., 2012; Keese, 2008).

Despite that, consumption of products (e.g. milk, meat, egg) from animals fed GM feed is a public concern in most countries (Wong \& Chan, 2016). The debate on the impact of GM food on the health of humans and animals is still in progress. In many studies, there were only small differences, with non-biological significance, observed between GM and non-GM feed groups (Domingo, 2016; He et al., 2016; Qi et al., 2012). On the other hand, other studies indicate serious health problems associated with the consumption of GM food (Séralini et al., 2014).

Among the widely used GM is the Roundup Ready ${ }^{\bullet}$ GM soya, a glyphosate-resistant soybean developed by Monsanto company, and it is contributed to more than $70 \%$ of soybean production (Millstone, Brunner, \& Mayer, 1999). Roundup ready soybeans express a form of an enol pyruvate shikimate-3-phosphate synthase (EPSPS) that encodes a protein capable of degrading glyphosate (Raffaella, Serena, Isabella, Vincenzo, \& Federico, 2011).

Due to insufficient data from risk assessment regarding the influence of using transgenic soybean meal in animal feed, in this study we aim to evaluate the biological risks associated with the feeding of Roundup Ready GM soybean meal (RUR) on female and male Wistar rats based on growth performance, selected organs weight, blood chemistry, and histopathological examination.

\section{Methods}

\section{Assessment of the meal ingredients and experimental} diet

GM soybean meal was obtained from an Egyptian company (source: BUNGE Argentina S.A., Buenos Aires, Argentina) and non-GM soybean meal was bought from The Soy Factory, Agricultural Research Center, Giza, Egypt. Non-GM and GM soybean meal were first tested for the presence of GM Soybean (RUR) using specific primers for the 35S promoter (size of $195 \mathrm{bp}$ ) and EPSPS'EPSPS_RUR' (size of $172 \mathrm{bp}$ ) regions. Expected PCR amplification products were detected only in GM soybean meal (Additional file 1: Figure S1 and S2). PCR amplification was carried out using thermal cycler PCR (BIO-RAD T100, Michigan, USA). The reaction mixture was subjected to an initial denaturation at $95{ }^{\circ} \mathrm{C}$ for
5 min followed by 40 cycles repeated of 1 min denaturation at $95{ }^{\circ} \mathrm{C}, 1 \mathrm{~min}$ annealing at $60{ }^{\circ} \mathrm{C}$ for EPSPS_RUR while at $56{ }^{\circ} \mathrm{C}$ for $35 \mathrm{~S}$ and $5 \mathrm{~min}$ extension at $72{ }^{\circ} \mathrm{C}$. Primers sets used for amplification were listed in Table 1; the used primers were obtained from Biolegio BV (Nijmegen, The Netherlands).

Crude protein, moisture, crude fiber, ash, fat, total aflatoxins content, calcium and phosphorus, amino acid, fatty acid profile, and the concentration of glyphosate in non-GM, GM soybean meal, and ingredients of the experimental diet were analyzed at Regional Center for Food and Feed (RCFF), Egypt, using an appropriate tools and according to established protocol at RCFF according to the official method of analysis of Association of Official Analytical Chemists (AOAC, 2012) international.

\section{Feed ingredient and experimental diet}

Three experimental diets were used in this study (Table 2). The first was the control diet, which was formulated to contain 30\% non-GM soybean meal (0\% GM soybean meal). The second is a treatment diet (hereafter called T1) which contained 30\% soybean meal, where half of this percentage came from Non- GM soybean meal and the other half came from GM soybean meal (50\% GM soya). The last diet (hereafter-called T2), which was formulated to contain 30\% GM soybean meal, all came from GM soybean meal (100\% GM soya). In the three-formulated diets, casein was used to fulfill protein requirement for rats. All diets were supplied with minerals and vitamins as previously described (Reeves, Nielsen, \& Fahey, 1993; Teshima et al., 2000).

\section{Animals and housing}

Sixty weaned Wistar albino rats (30 females and 30 males) were obtained from the laboratory animal house facility of the Ophthalmic Research Institute, Giza, Egypt. Upon arrival, the rats were randomly transferred to stainless-steel cages and allowed to acclimatize for two weeks before the start of the experiment. The body weight of the animals was around $70 \mathrm{~g}$ at the beginning of the experiment. The rats were randomly divided into three groups of ten rats for each group per each sex. Rats were a pair housed in a clean stainless-steel cage at ambient temperature (25 \pm

Table 1 Primer pairs used in the current study

\begin{tabular}{llll}
\hline Target & Sequence(s) & $\mathrm{Ta}^{\circ} \mathrm{C}$ & Amplicon size \\
\hline 35S Promoter & Forward primer: 5' GCTC & $56^{\circ} \mathrm{C}$ & $195 \mathrm{bp}$ \\
& CTACAAATGCCATCA 3' & & \\
& Reverse primer: 5' GATA & & \\
& GTGGGATTGTGCGTCA 3' & & \\
EPSPS_RUR & Forward primer:5' TGATGT & $60^{\circ} \mathrm{C}$ & $172 \mathrm{bp}$ \\
& GATATCTCCACTGACG 3' & & \\
& Reverse primer:5' TGTA & & \\
& TCCCTTGAGCCATGTTT 3' & \\
\hline
\end{tabular}


Table 2 Composition of the experimental diets ( $\mathrm{g} / 100 \mathrm{~g}$ dry matter) formulated according to Teshima et al., 2000

\begin{tabular}{|c|c|c|c|}
\hline Ingredients & Control & $\mathrm{T} 1$ & $\mathrm{~T} 2$ \\
\hline Soybean & 30.00 & 30.00 & 30.00 \\
\hline Casein & 5.42 & 4.91 & 4.40 \\
\hline Corn starch & 39.83 & 38.84 & 37.85 \\
\hline Sucrose & 10.00 & 10.00 & 10.00 \\
\hline Cellulose & 5.00 & 5.00 & 5.00 \\
\hline Corn oil & 3.00 & 4.50 & 6.00 \\
\hline Minerals $^{a}$ & 3.50 & 3.50 & 3.50 \\
\hline Vitamins $^{b}$ & 1.00 & 1.00 & 1.00 \\
\hline Choline & 0.25 & 0.25 & 0.25 \\
\hline $\mathrm{CaCO}_{3}$ & 0.90 & 0.90 & 0.90 \\
\hline $\mathrm{CaHPO}_{4}$ & 1.10 & 1.10 & 1.10 \\
\hline
\end{tabular}

${ }^{a}$ Minerals at $3.50 \%$ of the diet supplies the following per $100 \mathrm{~g}$ of the diet; mono potassium phosphate $19.6 \%$, potassium citrate monohydrate $7.078 \%$, sodium chloride $7.4 \%$, potassium sulphate $4.66 \%$, magnesium oxide $2.4 \%$, ferric citrate $0.606 \%$, zinc carbonate $0.165 \%$, manganese carbonate $0.063 \%$, copper carbonate $0.03 \%$, potassium iodate $0.001 \%$, sodium selenate anhydrous $0.00103 \%$, ammonium molybdate tetra hydrate $0.000795 \%$, sodium meta silicate $9 \mathrm{H}_{2} \mathrm{O} 0.145 \%$, chromium potassium sulphate dodeca hydrate $0.0275 \%$, lithium chloride $0.00174 \%$, boric acid $0.008145 \%$, sodium fluoride $0.00635 \%$, nickel carbonate $0.00318 \%$, ammonium vanadate $0.00066 \%$, and powdered sucrose $22.1 \%$. Mineral mixture was proposed by (Reeves et al., 1993)

${ }^{b}$ Vitamins at $1 \%$ of the diet supplies the following per $100 \mathrm{~g}$ of the diet: Nicotinic acid $0.3 \mathrm{~g}$, D-calcium pantothenate $0.16 \mathrm{~g}$, pyridoxine HCL $0.07 \mathrm{~g}$, Thiamine HCL, $0.06 \mathrm{~g}$, Riboflavin $0.06 \mathrm{~g}$, Folic acid $0.02 \mathrm{~g}$, D-biotin $0.002 \mathrm{~g}$, vitamin $B_{12},(0.1 \%$ triturated in mannitol $0.25 \mathrm{~g}$, a-tocopherol $(250 \mathrm{U} / \mathrm{g}) 3 \mathrm{~g}$, vitamin A palmitate $(250,000 \mathrm{U} / \mathrm{g}) 0.16 \mathrm{~g}$, vitamin $\mathrm{D}_{3}(400,000 \mathrm{U} / \mathrm{g}) 0.025 \mathrm{~g}$ Phylloquinone $0.0075 \mathrm{~g}$, and powdered sucrose $95.9 \mathrm{~g}$. Vitamin mixture was proposed by (Reeves et al., 1993)

$5{ }^{\circ} \mathrm{C}$ ) and relative humidity (46-61\%). Water and diets were offered ad libitum. The experimental work was carried out at RCFF, in accordance with the national guidelines for care and use of laboratory animals.

\section{Experimental procedures}

During the study, control diet was presented as a sole diet for all rats during the period of acclimatization that extend for 2 weeks. Three groups of ten males and three groups of ten females fed a diet containing 0\% GM soybean meal (control), 50\% GM soybean meal (T1), and $100 \%$ GM soybean (T2) for 18 weeks. The rats were checked twice daily for any signs of toxicity or morphological changes. Body weight and feed intake were recorded once a week. At the end of this period, the rats were euthanized, and blood samples were collected from the orbital sinus.

The blood samples were collected in tubes containing disodium ethylene di-amine tetra acetate dihydrate (EDTA- $\mathrm{Na}_{2}$ ), for biochemical analyses. Two aliquots of plasma and sera were prepared for all rats and stored at $-20{ }^{\circ} \mathrm{C}$ for biochemical analyses. Two euthanized rats from both sex were randomly chosen from each group and four organs were selected. Selected organs are the kidney, the liver, the pancreas, the gonads (testis or ovary), and female mammary gland for histopathological examination.

\section{Growth performance and nutrient utilization}

Growth and nutrient utilization parameters were monitored and analyzed in terms of final body weight (FBW), weight gain (WG) (weight gain = final body weight - initial body weight), feed intake (FI) (feed intake = amount of feed eaten - feed remained), and feed conversion ratio (FCR) (feed conversion = feed intake/weight gain), according to Pierozan et al., 2016.

\section{Hematological and biochemical blood analysis}

Blood sample collected from the orbital sinus were assayed using BC-2800Vet Auto Hematology Analyzer (Mindray, China) at the Faculty of Agriculture Research Park (FARP), Cairo University for the following hematological parameters: white blood cell count (WBC), red blood cell count (RBC), hemoglobin (HGB) hematocrit (HCT).

The following serum parameters including lactic dehydrogenase (LDH), alanine aminotransferase (ALT), alkaline phosphatase (ALP), aspartate aminotransferase (AST), total protein (TP), albumin (ALB), creatinine (CREA) glucose (GLU), calcium $(\mathrm{Ca})$, phosphorus $(\mathrm{P})$, total cholesterol $(\mathrm{CHO})$, and triglycerides (TG) were analyzed using a fully automated dry chemistry analyzer (Vitros 350, USA) Ortho clinical diagnostic at RCFF.

\section{Histopathological examination}

Two rats were randomly selected from each of the studied group for histopathological investigations. Tissue samples, from vital organs (liver, pancreas, and kidney), and goands were fixed in $10 \%$ formalin, embedded in paraffin and sectioned to obtain $4 \mu \mathrm{m}$ thickness paraffin sections by a slidge microtome. The obtained tissue sections were collected on glass slides, deparaffinized in xylene, hydrated in descending series of ethyl alcohol, stained by hematoxylin and eosin stains $(H \& E)$, dehydrated in ascending series of ethyl alcohol, cleared in two changes of xylene, mounted with DPX (Bancroft \& Gamble, 2008), and then examined with light microscope.

\section{Mammary gland examination Mammary gland whole mount}

Whole mounts were prepared by excising the fourth inguinal mammary gland pairs from female rats at week 18. Fourth mammary glands were dissected from the inner surface of the skin, then were spread onto a slide, placed in Carnoy's fixative solution, and with a carmine aluminum solution (De Assis, Warri, Cruz, \& HilakiviClarke, 2010). The morphology of whole mount samples preparation was examined to evaluate the size of the 
mammary gland, the number of terminal end buds, and ductal growth (elongation).

\section{Mammary gland histology sections}

Mammary tissues (inguinal fourth gland) were collected and processed for paraffin blocks preparation. Five micrometer sections of mammary tissue were cut and stained with hematoxylin and eosin for the histological evaluation. Meanwhile, the mammary gland tissue sections were stained with picrosirus red to evaluate extracellular matrix (ECM)-associated collagen (Ding et al., 2013). For picrosirus red staining, sections were deparaffinized with two changes of Xylene for $10 \mathrm{~min}$, followed by two changes of absolute ethanol for $5 \mathrm{~min}$, and then sections were hydrated with tap water. Sections were stained withpicrosirius red stain for $1 \mathrm{~h}$ at $\mathrm{RT}$, and then washed in two changes of $0.1 \%$ acetic acid. Sections were then dehydrated with ethanol, cleared in xylene, and then mounted with DPX.

\section{Statistical analysis}

Obtained data were analyzed using IBM SPSS Statistics for Windows (Version 23, IBM Corp., NY, USA). Twoway analysis of variance (ANOVA) was used to study the effect of gender (female and male), diet type $(0 \%, 50 \%$ and $100 \%$ of GM soybean meal), and their interaction together on all the examined parameters. Duncan's test was utilized to examine the similarities among all the experimental groups. Independent $t$ test was conducted to compare between female and male groups. Regression analysis and correlation coefficient analysis were applied to study the relationships between the weight gain and feeding duration. Data were expressed as a mean \pm standard error of the mean (SEM).

\section{Results}

Feed ingredients analysis

Non-GM and GM soybean meal contained comparable levels of crude protein, moisture, ash, crude fiber, calcium and phosphorus, amino acids, and fatty acids (Additional file 2: Tables S1-S3).Glyphosate residues were detected in GM soybean at the level of $2.68 \mathrm{mg} / \mathrm{kg}$. However, when diet was formulated, the glyphosate level reached $0.89 \mathrm{mg} / \mathrm{kg}$ in the experimental diet $(100 \% \mathrm{GM}$ soybean meal). Aflatoxin contamination was only detected in the control diet at the level of $5 \mathrm{ppb}$. The experimental diets were formulated to fulfill the nutrient requirements of the rats (Table 2). These data suggested the analyzed soybean meal (as feed-base) and the composition of the experimental diets and contaminants were at levels that will not affect the output of this study (Bøhn et al., 2014; Unnevehr \& Grace, 2013).

\section{Mortality and growth performance}

No sign of mortality has occurred during the 18 weeks of animals feeding course of this study. Across the experimental period, normal activities were detected for rats from both sex and fed at a different ratio of GM soybean meals. No treatment-related differences were detected among all groups (T1 and T2) with their respective controls in final body weight, feed intake, body weight gain, and feed conversion at different ratio of GM feeds $(0 \%, 50 \%$, and $100 \%$ GM soybean meals). Even though, significant genderassociated differences in body weight were detected in male groups in comparison female groups (Table 3). These differences can be interpreted to food preferences and food consumption between the two genders.

\section{Organ weights}

No significant differences detected among all groups with their respective controls at different ratio of GM feed $(0 \%, 50 \%$, and $100 \%$ GM soybean meals) in average organs weight (liver, kidney, spleen, heart, brain, lung, and gonads). A difference in some organs weight was detected in male groups with their respective female groups in this studied population, and this biological difference is unrelated to treatment (Table 4).

\section{Hematological and biochemical blood analysis}

Examined hematological parameters did not show a significant difference between the GM soybean meal fed groups (T1 and $\mathrm{T} 2)$ and their respective controls, though the WBC of the male 50\% and 100\% treated group (T1 and T2), platelets count of the female, and HB of 50\% GM soybean meal group (T1) were slightly elevated. The observed gender-associated differences between male and female groups can be interrupted by biological variation between the two genders and unrelated to treatment, as it is close to the ranges of the control groups (Table 5).

Most of the examined biochemical blood parameters did not show a significant difference between the GM soybean-fed groups (T1 and T2) compared to their control groups. However, the level of triglycerides (TG) was significantly higher in the female treated group (T1 and T2) and LDH was significantly higher in treated groups compared to their respective controls. Elevated levels of ALP, AST, ALT, and creatinine were observed in some of the treated groups that can be interpreted as a reflection of histopathological alterations of the liver and kidney structure and functions in these groups (Table 6).

\section{Histopathological examination}

Histopathological examination of selected organs (liver, kidney, and pancreas) and the testes or ovaries revealed subtle histological alterations among different treated groups (T1 and T2) with their respective controls. 
Table 3 The effect of gender, percentage of GM soybean in the experimental diets (0\%, 50\%, and 100\% GM soya), and their interaction on the body weights, food consumption, and conversion in albino rats. Results are represented as mean \pm standard error of mean

\begin{tabular}{|c|c|c|c|c|c|c|c|}
\hline \multirow[t]{2}{*}{ Parameter } & \multicolumn{4}{|c|}{ Experimental group } & \multicolumn{3}{|l|}{ Effect of } \\
\hline & Gender & Control & $\mathrm{T1}$ & $\mathrm{T} 2$ & Gender & Diet & Interaction \\
\hline \multirow[t]{2}{*}{ Initial body weight (g) } & Female & $91.86 \pm 3.45^{\mathrm{A}}$ & $88.04 \pm 2.86^{\mathrm{A}}$ & $92.18 \pm 3.59^{A}$ & \multirow{2}{*}{$\begin{array}{l}F 1,24=2.26 \\
P>0.05\end{array}$} & \multirow{2}{*}{$\begin{array}{l}F 2,24=0.33 \\
P>0.05\end{array}$} & \multirow{2}{*}{$\begin{array}{l}F 2,24=0.21, \\
P>0.05\end{array}$} \\
\hline & Male & $87.82 \pm 1.29^{\mathrm{A}}$ & $84.16 \pm 6.89^{A}$ & $82.96 \pm 6.91^{\mathrm{A}}$ & & & \\
\hline \multirow[t]{2}{*}{ Final body weight (g) } & Female & $234.32 \pm 11.92^{\mathrm{A}}$ & $223.50 \pm 6.94^{\mathrm{A}}$ & $214.38 \pm 7.99^{\mathrm{A}}$ & \multirow{2}{*}{$\begin{array}{l}F 1,24=86.94 \\
P<0.001\end{array}$} & \multirow{2}{*}{$\begin{array}{l}F 2,24=0.07 \\
P>0.05\end{array}$} & \multirow{2}{*}{$\begin{array}{l}F 2,24=0.37, \\
P>0.05\end{array}$} \\
\hline & Male & $367.66 \pm 26.52^{\mathrm{A}^{*}}$ & $364.22 \pm 29.85^{\mathrm{A}^{*}}$ & $379.32 \pm 19.18^{\mathrm{A}^{*}}$ & & & \\
\hline \multirow[t]{2}{*}{ Weight gain (g) } & Female & $142.46 \pm 13.05^{\mathrm{A}}$ & $135.46 \pm 8.26^{\mathrm{A}}$ & $122.20 \pm 8.57^{\mathrm{A}}$ & \multirow{2}{*}{$\begin{array}{l}F 1,24=80.78 \\
P<0.001\end{array}$} & \multirow{2}{*}{$\begin{array}{l}F 2,24=0.16 \\
P>0.05\end{array}$} & \multirow{2}{*}{$\begin{array}{l}F 2,24=0.22, \\
P>0.05\end{array}$} \\
\hline & Male & $279.84 \pm 26.68^{A^{*}}$ & $280.06 \pm 33.29^{A^{*}}$ & $296.36 \pm 19.05^{\mathrm{A}^{*}}$ & & & \\
\hline \multirow[t]{2}{*}{ Food consumption } & Female & $2541.69 \pm 91.04^{\mathrm{A}}$ & $2399.02 \pm 50.77^{\mathrm{A}}$ & $2412.62 \pm 35.36^{A}$ & \multirow{2}{*}{$\begin{array}{l}F 1,24=71.09 \\
P<0.001\end{array}$} & \multirow{2}{*}{$\begin{array}{l}F 2,24=1.45 \\
P>0.05\end{array}$} & \multirow{2}{*}{$\begin{array}{l}F 2,24=4.39, \\
P<0.05\end{array}$} \\
\hline & Male & $2970.30 \pm 243.60^{A}$ & $3446.50 \pm 97.99^{A^{*}}$ & $3489.54 \pm 103.08^{\mathrm{A}^{*}}$ & & & \\
\hline \multirow[t]{2}{*}{ Food conversion } & Female & $18.37 \pm 1.55^{\mathrm{A}}$ & $17.94 \pm 1.01^{\mathrm{A}}$ & $20.13 \pm 1.40^{\mathrm{A}}$ & \multirow{2}{*}{$\begin{array}{l}F 1,24=23.50 \\
P<0.001\end{array}$} & \multirow{2}{*}{$\begin{array}{l}F 2,24=3.12 \\
P>0.05\end{array}$} & \multirow{2}{*}{$\begin{array}{l}F 2,24=2.32, \\
P>0.05\end{array}$} \\
\hline & Male & $11.12 \pm 1.45^{\mathrm{A}^{*}}$ & $12.96 \pm 1.45^{\mathrm{A}^{*}}$ & $11.95 \pm 0.75^{\mathrm{A}^{*}}$ & & & \\
\hline
\end{tabular}

* Represent significant differences $(P<0.05)$ in comparison to the corresponding female groups. In each row, the mean values marked with the same superscript letter are similar (insignificant, $P>0.05$ ), whereas those with different ones are significantly differed $(P<0.05)$. $P>0.05$ : insignificant, $P<0.05, P<0.01$ and $P<0.001$ : significant effect at $a=0.05,0.01$ and 0.001 , respectively

Liver tissue sections of treated groups showed a normal liver structure with basophilic focal necrotic areas, spontaneously focal and multifocal angiectasis (arrowheads) detected, that might occur as animals age. Sporadic zones of coagulation necrosis can be seen in male groups that received 50\% and 100\% GM soybean Fig. 1. Normal histological structures of kidneys, with signs of local inflammations (arrowheads), hemolysis (short arrows), and amyloid bodies (long arrow), were observed among treated groups (T1 and T2) compared to their respective controls (Fig. 2). Histological analyses of pancreatic tissue sections showed normal histological structure with normal beta cells shape and distribution in $50 \%$ GM soybean meal groups, and beta cells, while signs of hemolysis and amyloidosis (white arrows) and neutrophil infiltration and non-malignant pancreatic fibrosis (yellow arrows) were detected in $100 \%$ soybean meal groups (Fig. 3).

Table 4 The effect of gender, percentage of GM soybean in the experimental diets (0\%, 50\%, and 100\% GM soya), and their interaction on the organ weights of albino rats. Results are represented as mean \pm standard error of mean

\begin{tabular}{|c|c|c|c|c|c|c|c|}
\hline \multirow[t]{2}{*}{ Parameter } & \multicolumn{4}{|c|}{ Experimental group } & \multicolumn{3}{|l|}{ Effect of } \\
\hline & Gender & Control & $\mathrm{T} 1$ & $\mathrm{~T} 2$ & Gender & Diet & Interaction \\
\hline \multirow[t]{2}{*}{ Liver (mg) } & Female & $24.72 \pm 1.01^{\mathrm{A}}$ & $25.80 \pm 0.97^{\mathrm{A}}$ & $28.22 \pm 1.50^{\mathrm{A}}$ & \multirow{2}{*}{$\begin{array}{l}F 1,24=29.77 \\
P<0.001\end{array}$} & \multirow{2}{*}{$\begin{array}{l}F 2,24=1.32 \\
P>0.05\end{array}$} & \multirow{2}{*}{$\begin{array}{l}F 2,24=1.23, \\
P>0.05\end{array}$} \\
\hline & Male & $21.40 \pm 1.69^{\mathrm{A}}$ & $20.20 \pm 0.58^{A^{*}}$ & $21.20 \pm 1.07^{\mathrm{A}^{*}}$ & & & \\
\hline \multirow[t]{2}{*}{ Kidney (mg) } & Female & $3.22 \pm 0.20^{\mathrm{A}}$ & $3.50 \pm 0.14^{\mathrm{A}}$ & $3.42 \pm 0.21^{\mathrm{A}}$ & \multirow{2}{*}{$\begin{array}{l}F 1,24=11.63 \\
P<0.01\end{array}$} & \multirow{2}{*}{$\begin{array}{l}F 2,24=0.13 \\
P>0.05\end{array}$} & \multirow{2}{*}{$\begin{array}{l}\mathrm{F} 2,24=2.02, \\
P>0.05\end{array}$} \\
\hline & Male & $3.10 \pm 0.20^{A}$ & $2.62 \pm 0.25^{\mathrm{A}^{*}}$ & $2.80 \pm 0.12^{\mathrm{A}^{*}}$ & & & \\
\hline \multirow[t]{2}{*}{ Spleen (mg) } & Female & $2.04 \pm 0.17^{A}$ & $1.82 \pm 0.07^{\mathrm{A}}$ & $1.78 \pm 0.07^{\mathrm{A}}$ & \multirow{2}{*}{$\begin{array}{l}F 1,24=0.29 \\
P>0.05\end{array}$} & \multirow{2}{*}{$\begin{array}{l}F 2,24=0.30 \\
P>0.05\end{array}$} & \multirow{2}{*}{$\begin{array}{l}\mathrm{F} 2,24=0.10, \\
P>0.05\end{array}$} \\
\hline & Male & $1.54 \pm 0.22^{A}$ & $1.20 \pm 0.18^{A}$ & $1.72 \pm 0.15^{\mathrm{A}}$ & & & \\
\hline \multirow[t]{2}{*}{ Heart (mg) } & Female & $3.77 \pm 0.17^{\mathrm{A}}$ & $3.80 \pm 0.21^{\mathrm{A}}$ & $4.40 \pm 0.21^{\mathrm{A}}$ & \multirow{2}{*}{$\begin{array}{l}F 1,24=13.67 \\
P<0.01\end{array}$} & \multirow{2}{*}{$\begin{array}{l}F 2,24=1.94 \\
P>0.05\end{array}$} & \multirow{2}{*}{$\begin{array}{l}F 2,24=1.51, \\
P>0.05\end{array}$} \\
\hline & Male & $3.42 \pm 0.15^{\mathrm{A}}$ & $3.38 \pm 0.24^{\mathrm{A}}$ & $3.44 \pm 0.15^{A^{*}}$ & & & \\
\hline \multirow[t]{2}{*}{ Brain (mg) } & Female & $7.10 \pm 0.35^{A}$ & $7.82 \pm 0.44^{\mathrm{A}}$ & $7.40 \pm 0.24^{A}$ & \multirow{2}{*}{$\begin{array}{l}F 1,24=78.28 \\
P<0.001\end{array}$} & \multirow{2}{*}{$\begin{array}{l}F 2,24=0.91 \\
P>0.05\end{array}$} & \multirow{2}{*}{$\begin{array}{l}\mathrm{F} 2,24=0.61, \\
P>0.05\end{array}$} \\
\hline & Male & $4.90 \pm 0.37^{A^{*}}$ & $4.96 \pm 0.36^{\mathrm{A}^{*}}$ & $4.46 \pm 0.42^{\mathrm{A}^{*}}$ & & & \\
\hline \multirow[t]{2}{*}{ Lung (mg) } & Female & $5.30 \pm 0.65^{A}$ & $5.40 \pm 0.18^{A}$ & $5.64 \pm 0.50^{A}$ & \multirow{2}{*}{$\begin{array}{l}F 1,24=9.24 \\
P<0.01\end{array}$} & \multirow{2}{*}{$\begin{array}{l}F 2,24=0.08 \\
P>0.05\end{array}$} & \multirow{2}{*}{$\begin{array}{l}F 2,24=0.24, \\
P>0.05\end{array}$} \\
\hline & Male & $4.42 \pm 0.42^{\mathrm{A}}$ & $4.62 \pm 0.24^{\mathrm{A}^{*}}$ & $4.34 \pm 0.17^{\mathrm{A}^{*}}$ & & & \\
\hline Testis (mg) & Male & $4.00 \pm 0.28^{A}$ & $4.02 \pm 0.28^{A}$ & $4.26 \pm 0.20^{A}$ & - & $\begin{array}{l}F 2,14=0.324 \\
P>0.05\end{array}$ & - \\
\hline Ovary (mg) & Female & ND & ND & ND & - & - & - \\
\hline
\end{tabular}

* Represent significant differences $(P<0.05)$ in comparison to the corresponding female groups. In each row, the mean values marked with the same superscript letter are similar (insignificant, $P>0.05$ ), whereas those with different ones are significantly differed $(P<0.05)$. $P>0.05$ : insignificant, $P<0.05, P<0.01$ and $P<0.001$ : significant effect at $a=0.05,0.01$ and 0.001 , respectively. ND not detected 
Table 5 The effect of gender, percentage of GM soybean in the experimental diets (0\%, 50\%, and 100\% GM soya), and their interaction on the levels of certain hematological parameters in albino rats. Results are represented as mean \pm standard error of mean

\begin{tabular}{|c|c|c|c|c|c|c|c|}
\hline \multirow[t]{2}{*}{ Parameter } & \multicolumn{4}{|c|}{ Experimental group } & \multicolumn{3}{|l|}{ Effect of } \\
\hline & Gender & Control & $\mathrm{T} 1$ & $\mathrm{~T} 2$ & Gender & Diet & Interaction \\
\hline \multirow[t]{2}{*}{$\overline{\mathrm{WBC}\left(10^{9} / \mathrm{L}\right)}$} & Female & $8.72 \pm 0.68^{A}$ & $9.44 \pm 1.07^{A}$ & $9.76 \pm 0.57^{A}$ & \multirow{2}{*}{$\begin{array}{l}F 1,24=12.21 \\
P<0.01\end{array}$} & \multirow{2}{*}{$\begin{array}{l}F 2,24=2.89, \\
P>0.05\end{array}$} & \multirow{2}{*}{$\begin{array}{l}F 2,24=1.68, \\
P>0.05\end{array}$} \\
\hline & Male & $10.30 \pm 0.95^{\mathrm{A}}$ & $13.84 \pm 1.14^{B^{*}}$ & $11.36 \pm 0.76^{\mathrm{AB}}$ & & & \\
\hline \multirow[t]{2}{*}{$\operatorname{RBC}\left(10^{12} / L\right)$} & Female & $8.81 \pm 0.09^{\mathrm{AB}}$ & $9.05 \pm 0.13^{B}$ & $8.52 \pm 0.20^{A}$ & \multirow{2}{*}{$\begin{array}{l}F 1,24=21.14 \\
P<0.001\end{array}$} & \multirow{2}{*}{$\begin{array}{l}F 2,24=0.90 \\
P>0.05\end{array}$} & \multirow{2}{*}{$\begin{array}{l}F 2,24=2.80, \\
P>0.05\end{array}$} \\
\hline & Male & $9.26 \pm 0.17^{A^{*}}$ & $9.34 \pm 0.15^{\mathrm{A}}$ & $9.50 \pm 0.15^{A^{*}}$ & & & \\
\hline \multirow[t]{2}{*}{$\operatorname{PLT}\left(10^{9} / \mathrm{L}\right)$} & Female & $1069.20 \pm 33.65^{\mathrm{A}}$ & $1289.00 \pm 58.45^{B}$ & $1076.60 \pm 43.12^{A}$ & \multirow{2}{*}{$\begin{array}{l}F 1,24=1.47 \\
P>0.05\end{array}$} & \multirow{2}{*}{$\begin{array}{l}F 2,24=2.98 \\
P>0.05\end{array}$} & \multirow{2}{*}{$\begin{array}{l}F 2,24=6.80, \\
P<0.01\end{array}$} \\
\hline & Male & $1277.20 \pm 56.00 A^{A^{*}}$ & $1155.00 \pm 37.48^{\mathrm{A}^{*}}$ & $1140.80 \pm 45.43^{\mathrm{A}}$ & & & \\
\hline \multirow[t]{2}{*}{$\mathrm{Hb}(\mathrm{g} / \mathrm{dl})$} & Female & $14.10 \pm 0.28^{A B}$ & $14.80 \pm 0.26^{B}$ & $13.86 \pm 0.27^{A}$ & \multirow{2}{*}{$\begin{array}{l}F 1,24=0.94 \\
P>0.05\end{array}$} & \multirow{2}{*}{$\begin{array}{l}\mathrm{F} 2,24=1.44 \\
P>0.05\end{array}$} & \multirow{2}{*}{$\begin{array}{l}F 2,24=1.60, \\
P>0.05\end{array}$} \\
\hline & Male & $13.92 \pm 0.24^{\mathrm{A}}$ & $14.04 \pm 0.39^{A}$ & $14.12 \pm 0.27^{\mathrm{A}}$ & & & \\
\hline \multirow[t]{2}{*}{ Hct (\%) } & Female & $47.00 \pm 3.03^{\mathrm{A}}$ & $52.18 \pm 0.95^{\mathrm{A}}$ & $46.88 \pm 0.57^{\mathrm{A}}$ & \multirow{2}{*}{$\begin{array}{l}F 1,24=0.199 \\
P>0.05\end{array}$} & \multirow{2}{*}{$\begin{array}{l}F 2,24=2.85 \\
P>0.05\end{array}$} & \multirow{2}{*}{$\begin{array}{l}F 2,24=1.76 \\
P>0.05\end{array}$} \\
\hline & Male & $48.72 \pm 0.96^{\mathrm{A}}$ & $48.58 \pm 1.08^{\mathrm{A}^{*}}$ & $47.16 \pm 0.61^{A}$ & & & \\
\hline
\end{tabular}

* Represents significant differences $(P<0.05)$ in comparison to the corresponding female groups. In each row, the mean values marked with the same superscript letter are similar (insignificant, $P>0.05$ ) whereas those with different ones are significantly differed $(P<0.05)$. $P>0.05$ : insignificant, $P<0.05, P<0.01$ and $P<0.001$ : significant effect at $a=0.05,0.01$, and 0.001 , respectively

Histopathological examination of gonads in male and female Wistar rats fed with GM food. Tissue sections of paraffin-embedded ovaries showed normal cortical stroma, primordial, primary, and secondary follicles among different groups of this study, with a lower follicular count in 100\% GM soybean group (Fig. 4a-c). While, tissue sections of paraffin-embedded testes structures show atrophy of seminiferous tubular atrophy, for some extent, thinning of the tubule wall and the absence of spermatozoa in some tubule lumen (arrowhead) in $50 \%$ GM soybean group (T1), and seminiferous tubule dilation was detected in 100\% GM soybean group (T2), compared to their respective control group (Fig. $4 \mathrm{~d}-\mathrm{f}$ ).

\section{Morphological and histopathological examination of female mammary glands}

The examination of whole mount preparations of the inguinal mammary glands of female Wistar rats showed no significant changes in the extent of mammary branching upon feeding with either low or high percentage of GM soybean meal (Fig. 5).

Microscopic analysis of mammary tissue sections showed a thickened, more prominent stromal/ECM layer around those ducts distant from lymph node region in the $100 \%$ GM soybean meal group, associated with signs of acini formation, though the animals were not pregnant and had passed puberty phase (Lucas et al., 2007; Rudmann, Cohen, Robbins, Coutant, \& Henck, 2005), whereas in low-dose treatment, the thickening was not evident and the periductal stroma was comparable to control ducts. Meanwhile, collagen analysis (picrosirus red staining) did not show drastic change in fibrous collagen network (collagen I/III) in mammary tissues upon treatment, more collagen deposition was noted with the thickened stromal layer around ducts with high dose treatment, in contrast to control and low dose treatment mammary tissues (Fig. 6).

\section{Discussion}

Currently, GM varieties of soybean are produced for animal feed (Nowicki et al., 2010). RURs is the major brand among those GM-soybeans cultivated. Animal experiments are providing valuable and important information relating to the safety of a GM plant for both animal and human consumption (Alexander et al., 2007). The present study is carried out to evaluate the biological risks associated with the feeding of RURGM soybean meal on Wistar albino rats based on examined biological parameters.

The examined hematological parameters did not show a significant difference between the GM soybean mealfed groups (T1 and T2) and their respective controls. In our study, elevated levels of ALP, AST, ALT, and creatinine were increased significantly in some of the treated groups can be considered as signs of alterations of the liver and kidney structure and functions. Different reports associate the elevated levels of these parameters with impaired liver and kidney function, in mice and rats fed the GM diet (Chawla \& Kellum, 2012; Limdi \& Hyde, 2003; Malatesta et al., 2002; Oraby, Kandil, Shaffie, \& Ghaly, 2015). Also, the raised level of triglycerides (TG) and LDH in the female treated group (T1 and T2) can be explained as indicative of liver problems and disruption of triglyceride metabolism (Séralini, Cellier, \& de Vendomois, 2007).

In the current study, histopathological examination of examined organs (liver, kidney, and pancreas) could reveal a sort of structural change. Liver tissue sections of 
Table 6 The effect of gender, percentage of GM soybean in the experimental diets (0\%, 50\%, and 100\% GM soya), and their interaction on the level of examined biochemical parameters in serum of albino rats. Results are represented as mean \pm standard error of mean

\begin{tabular}{|c|c|c|c|c|c|c|c|}
\hline \multirow[t]{2}{*}{ Parameter } & \multicolumn{4}{|c|}{ Experimental group } & \multicolumn{3}{|l|}{ Effect of } \\
\hline & Gender & Control & $\mathrm{T} 1$ & $\mathrm{~T} 2$ & Gender & Diet & Interaction \\
\hline \multirow[t]{2}{*}{$\overline{\mathrm{TG}}(\mathrm{mg} / \mathrm{dl})$} & Female & $46.86 \pm 1.80^{\mathrm{A}}$ & $63.08 \pm 3.58^{B}$ & $61.32 \pm 5.43^{B}$ & \multirow{2}{*}{$\begin{array}{l}F 1,24=0.009 \\
P>0.05\end{array}$} & \multirow{2}{*}{$\begin{array}{l}F 2,24=4.70 \\
P<0.05\end{array}$} & \multirow{2}{*}{$\begin{array}{l}F 2,24=2.37 \\
P>0.05\end{array}$} \\
\hline & Male & $53.52 \pm 3.98^{\mathrm{A}}$ & $52.66 \pm 2.59^{\mathrm{A}}$ & $64.10 \pm 5.79^{A}$ & & & \\
\hline \multirow[t]{2}{*}{ Chol (mg/dl) } & Female & $65.06 \pm 3.26^{A}$ & $67.26 \pm 6.44^{\mathrm{A}}$ & $51.88 \pm 4.70^{\mathrm{A}}$ & \multirow{2}{*}{$\begin{array}{l}F 1,24=3.98 \\
P>0.05\end{array}$} & \multirow{2}{*}{$\begin{array}{l}F 2,24=1.06 \\
P>0.05\end{array}$} & \multirow{2}{*}{$\begin{array}{l}F 2,24=2.39 \\
P>0.05\end{array}$} \\
\hline & Male & $65.02 \pm 0.73^{\mathrm{A}}$ & $71.14 \pm 4.84^{\mathrm{A}}$ & $72.20 \pm 6.96^{\mathrm{A}^{*}}$ & & & \\
\hline \multirow[t]{2}{*}{$\mathrm{HDL}$} & Female & $43.99 \pm 1.76^{\mathrm{A}}$ & $44.23 \pm 3.60^{A}$ & $35.77 \pm 3.79^{A}$ & \multirow{2}{*}{$\begin{array}{l}F 1,24=0.23 \\
P>0.05\end{array}$} & \multirow{2}{*}{$\begin{array}{l}F 2,24=0.73 \\
P>0.05\end{array}$} & \multirow{2}{*}{$\begin{array}{l}F 2,24=3.49 \\
P>0.05\end{array}$} \\
\hline & Male & $37.12 \pm 0.85^{\mathrm{A}^{*}}$ & $40.86 \pm 1.79^{A}$ & $42.79 \pm 3.25^{\mathrm{A}}$ & & & \\
\hline \multirow[t]{2}{*}{$\operatorname{TP}(g / d l)$} & Female & $6.98 \pm 0.23^{A}$ & $7.06 \pm 0.10^{\mathrm{A}}$ & $7.28 \pm 0.10^{\mathrm{A}}$ & \multirow{2}{*}{$\begin{array}{l}F 1,24=3.03 \\
P>0.05\end{array}$} & \multirow{2}{*}{$\begin{array}{l}F 2,24=5.72 \\
P<0.01\end{array}$} & \multirow{2}{*}{$\begin{array}{l}F 2,24=1.16 \\
P>0.05\end{array}$} \\
\hline & Male & $6.96 \pm 0.21^{\mathrm{A}}$ & $7.30 \pm 0.17^{A B}$ & $7.76 \pm 0.12^{\mathrm{B}^{*}}$ & & & \\
\hline \multirow[t]{2}{*}{ Alb (g/dl) } & Female & $5.14 \pm 0.19^{A}$ & $4.54 \pm 0.20^{\mathrm{A}}$ & $5.16 \pm 0.31^{\mathrm{A}}$ & \multirow{2}{*}{$\begin{array}{l}F 1,24=0.019 \\
P>0.05\end{array}$} & \multirow{2}{*}{$\begin{array}{l}F 2,24=3.32 \\
P>0.05\end{array}$} & \multirow{2}{*}{$\begin{array}{l}F 2,24=0.17 \\
P>0.05\end{array}$} \\
\hline & Male & $4.94 \pm 0.30^{\mathrm{A}}$ & $4.55 \pm 0.19^{\mathrm{A}}$ & $5.26 \pm 0.37^{\mathrm{A}}$ & & & \\
\hline \multirow[t]{2}{*}{ Glucose (mg/dl) } & Female & $108.60 \pm 5.28^{A}$ & $101.00 \pm 7.26^{\mathrm{A}}$ & $111.60 \pm 9.97^{A}$ & \multirow{2}{*}{$\begin{array}{l}F 1,24=18.11 \\
P<0.001\end{array}$} & \multirow{2}{*}{$\begin{array}{l}F 2,24=5.82 \\
P<0.01\end{array}$} & \multirow{2}{*}{$\begin{array}{l}F 2,24=4.17 \\
P<0.05\end{array}$} \\
\hline & Male & $173.60 \pm 8.48^{\mathrm{B}^{*}}$ & $116.60 \pm 9.61^{A}$ & $130.60 \pm 14.26^{A}$ & & & \\
\hline \multirow[t]{2}{*}{ Urea (mg/dl) } & Female & $42.22 \pm 2.07^{\mathrm{A}}$ & $39.82 \pm 3.44^{\mathrm{A}}$ & $41.40 \pm 2.82^{\mathrm{A}}$ & \multirow{2}{*}{$\begin{array}{l}F 1,24=10.84 \\
P<0.01\end{array}$} & \multirow{2}{*}{$\begin{array}{l}F 2,24=0.65 \\
P>0.05\end{array}$} & $F 2,24=0.33$ \\
\hline & Male & $34.20 \pm 0.96^{\mathrm{A}^{*}}$ & $33.48 \pm 1.06^{\mathrm{A}}$ & $37.12 \pm 2.45^{\mathrm{A}}$ & & & $P>0.05$ \\
\hline Creatinine & Female & $0.60 \pm 0.04^{A B}$ & $0.48 \pm 0.04^{\mathrm{A}}$ & $0.66 \pm 0.07^{B}$ & $F 1,24=15.78$ & $F 2,24=1.07$ & $F 2,24=7.48$ \\
\hline & Male & $0.64 \pm 0.04^{\mathrm{A}}$ & $0.86 \pm 0.05^{B^{*}}$ & $0.72 \pm 0.04^{\mathrm{A}}$ & & & \\
\hline $\operatorname{ALP}(U / L)$ & Female & $69.50 \pm 3.93^{\mathrm{A}}$ & $64.40 \pm 5.26^{\mathrm{A}}$ & $142.00 \pm 10.36^{B}$ & $F 1,24=8.45$ & $F 2,24=21.33$ & $F 2,24=31.39$ \\
\hline & Male & $133.40 \pm 6.23^{B^{*}}$ & $90.10 \pm 3.48^{\mathrm{A}^{*}}$ & $100.40 \pm 8.44^{\mathrm{A}^{*}}$ & & & \\
\hline AST (U/L) & Female & $159.20 \pm 13.47^{\mathrm{A}}$ & $245.40 \pm 10.62^{B}$ & $177.00 \pm 16.87^{A}$ & $F 1,24=0.71$ & $F 2,24=40.34$ & $F 2,24=3.28$ \\
\hline & Male & $116.00 \pm 7.60^{\mathrm{A}^{*}}$ & $247.20 \pm 3.57^{c}$ & $193.40 \pm 15.30^{B}$ & & & \\
\hline $\operatorname{ALT}(U / L)$ & Female & $34.00 \pm 3.51^{\mathrm{A}}$ & $32.40 \pm 3.54^{\mathrm{A}}$ & $48.40 \pm 5.84^{B}$ & $F 1,24=0.32$ & $F 2,24=2.34$ & $\mathrm{~F} 2,24=1.92$ \\
\hline & Male & $39.40 \pm 3.14^{\mathrm{A}}$ & $40.50 \pm 3.61^{\mathrm{A}}$ & $40.80 \pm 5.31^{\mathrm{A}}$ & & & \\
\hline $\mathrm{LDH}$ & Female & $1498.60 \pm 50.03^{\mathrm{A}}$ & $3436.80 \pm 263.30^{B}$ & $4049.00 \pm 160.87^{C}$ & $F 1,24=10.15$ & $F 2,24=97.08$ & $F 2,24=32.94$ \\
\hline & Male & $1214.40 \pm 18.58^{A^{*}}$ & $4348.00 \pm 215.41^{\mathrm{C}^{*}}$ & $1979.00 \pm 246.04^{B^{*}}$ & & & \\
\hline $\mathrm{Ca}(\mathrm{mg} / \mathrm{dl})$ & Female & $11.78 \pm 0.10^{\mathrm{A}}$ & $11.68 \pm 0.22^{\mathrm{A}}$ & $11.72 \pm 0.26^{\mathrm{A}}$ & $F 1,24=14.73$ & $F 2,24=3.19$ & $F 2,24=2.72$ \\
\hline & Male & $11.50 \pm 0.19^{B}$ & $11.22 \pm 0.23^{B}$ & $10.54 \pm 0.19^{\mathrm{A}^{*}}$ & & & \\
\hline $\mathrm{Ph}(\mathrm{mg} / \mathrm{dl})$ & Female & $4.55 \pm 0.21^{\mathrm{A}}$ & $5.74 \pm 0.74^{\mathrm{A}}$ & $4.36 \pm 0.52^{\mathrm{A}}$ & $F 1,24=0.13$ & $F 2,24=2.44$ & $F 2,24=0.28$ \\
\hline & Male & $4.74 \pm 0.44^{\mathrm{A}}$ & $5.16 \pm 0.62^{\mathrm{A}}$ & $4.29 \pm 0.46^{\mathrm{A}}$ & & & \\
\hline
\end{tabular}

* Represents significant differences $(P<0.05)$ in comparison to the corresponding female groups. In each row, the mean values marked with the same superscript letter are similar (insignificant, $P>0.05$ ) whereas those with different ones are significantly differed $(P<0.05) . P>0.05$ : insignificant, $P<0.05, P<0.01$ and $P<0.001$ : significant effect at $a=0.05,0.01$, and 0.001 , respectively

treated groups showed a normal liver structure with basophilic focal necrotic areas, with spontaneously focal and multifocal angiectasis. Similar to our results, several research groups reported that the GM soy (including RUR soybeans) could alter the cell structure and function of rats' liver (Ermakova, 2007; Malatesta et al., 2002; Oraby et al., 2015). Many of these changes reversed after diet was turned to non-GM soy, suggesting that GM soy was the cause (Malatesta et al., 2008).

Examined kidney showed signs of focal inflammations, hemolysis in the kidney tissues of treated groups compared to their respective controls. In consistence with our results, it has been reported that GM-fed animals showed signs of kidney inflammations, interstitial hemorrhage with changes in tubules (de Vendômois, Roullier, Cellier, \& Séralini, 2009; Oraby et al., 2015).

Examination of pancreatic tissue showed signs of hemolysis and amyloidosis and neutrophil infiltration and non-malignant pancreatic fibrosis in $100 \%$ soybean groups. Notably, normal histological structure with normal $\beta$ cells structure and distribution was observed in the 50\% GM soybean groups. Results of previous investigations showed that mice chronically fed RUR soy since gestation had problems in synthesis and processing of zymogens by pancreatic acinar cells and reduced nucleoplasmic and nucleolar and perichromatin granule accumulation on pancreatic acinar 

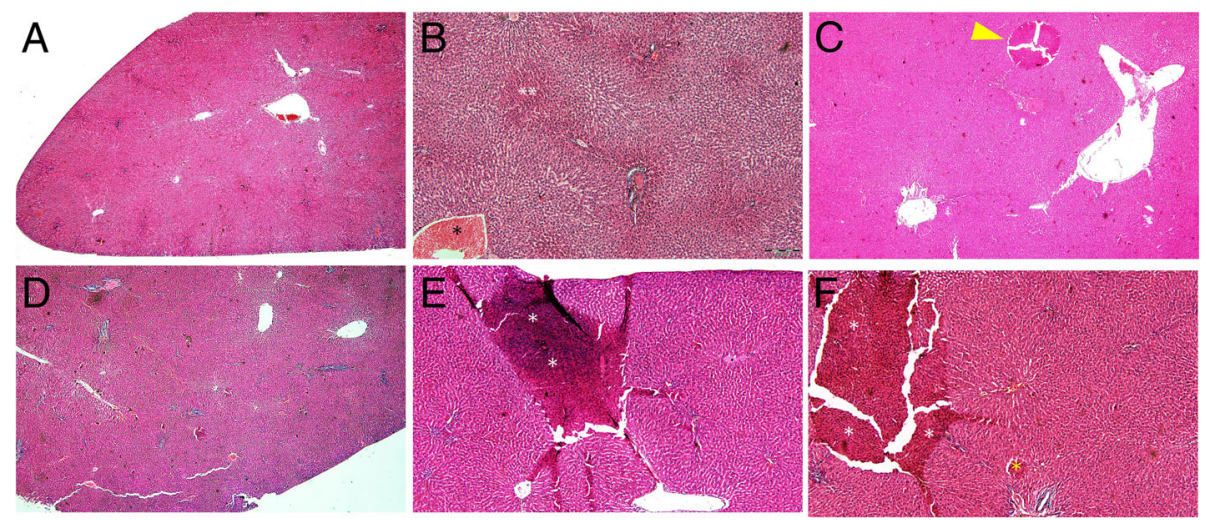

Fig. 1 Tissue sections representing histopathological results for liver examination using routine Hematoxylin \& Eosin (H\&E) stain. Upper panel (ac) are representatives of female liver sections and lower panel $(\mathbf{d}-\mathbf{f})$ are representatives of male liver sections, respectively. $\mathbf{a}$, $\mathbf{d}$ Images represents tissue sections of mice liver fed with 0\% GM soybean meal (control) group, showing no changes in morphology of hepatocytes. b Representative image of female rat liver fed with 50\% GM soybean showing basophilic focal necrotic areas (white stars) and blood congestion (yellow star). c Micrograph of represents tissue sections of female rat liver fed with 100\% GM soybean meal, showing moderate focal angiectasis (yellow arrowheads). d, e Micrograph of represents tissue sections of male rat liver fed with50\% and 100\% GM soybean meal respectively, showing moderate focal and multifocal angiectasis (white stars), sporadic zones of coagulation necrosis (yellow stars). Scale bar is $200 \mu \mathrm{m}$

cell nuclei (Brandt et al., 2017; Malatesta, Caporaloni, Rossi, et al., 2002; Mohamad et al., 2016). Amyloid occurs as a result of cells not being able to eliminate insoluble misfolded protein. It can be associated with overproduction of acutephase protein in chronic inflammation. Moreover, amyloid deposition is a common age-related change (Connors et al., 2016) and indicating a progressive organ damage (Milani et al., 2017).

Histopathological examination of testes in the current study showed seminiferous tubular atrophy with the absence of spermatozoa in some tubules in 50\% GM soybean group (T1) and seminiferous tubule dilation of the $100 \%$ GM soybean group (T2), compared to their respective control group. Similarity, previous scientific studies reported testicular alteration in rats fed RUR soybean (El-Shamei, Gab-Alla, Shatta, Moussa, \& Rayan, 2012). On the other hand, examined ovaries showed normal cortical stroma, primordial, primary and secondary follicles among different groups of this study, with a lower follicular count in $100 \%$ GM soybean group. These
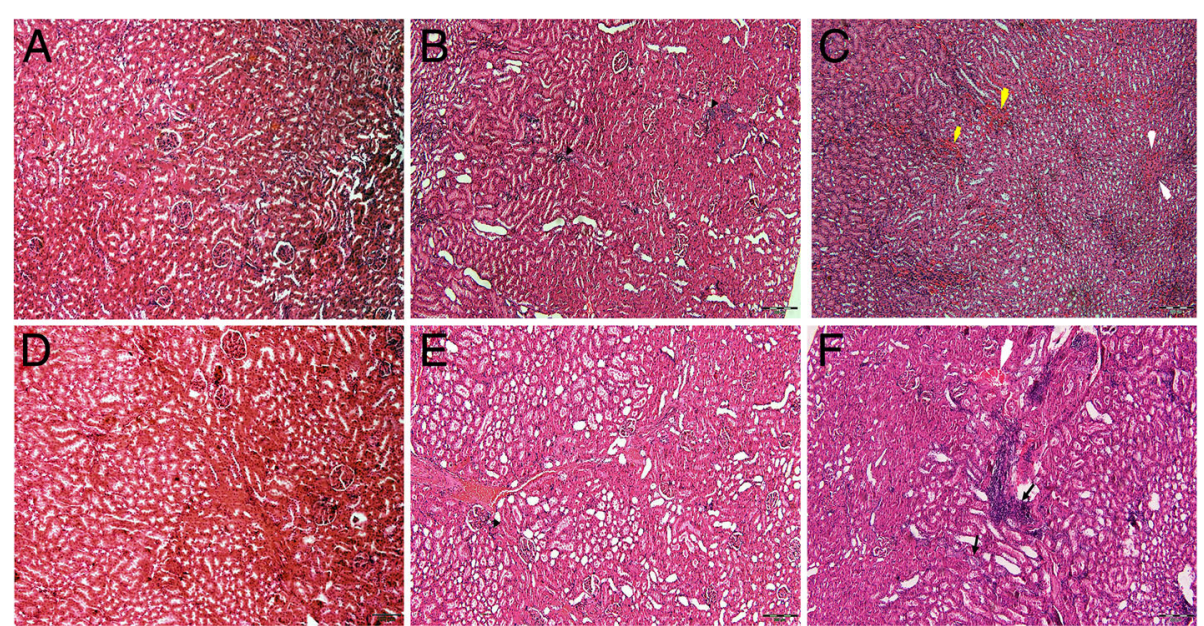

Fig. 2 Histopathological examination of kidney. Upper panel $(\mathbf{a}-\mathbf{c})$ and lower panel $(\mathbf{d}-\mathbf{f})$ showing histological structures of female and male kidney, respectively. a A representative micrograph of the control kidney of female rat showing normal structure. $\mathbf{b}$ The kidney section of rats fed $50 \%$ GM food areas of inflammation which indicated by black arrowhead. c The kidney of group fed 100\% GM food showing hemolysis in different areas of the kidney (yellow arrows) and amyloid bodies (white arrow). d A representative micrograph of male rats showing normal kidney structure. e The kidney section of group fed 50\% GM that showing infiltration of different inflammatory cells which indicated by arrowhead. $\mathbf{f}$ Represents the kidney of group fed 100\% GM food showing large inflammatory area (Black arrow), hemolysis in portal area of the kidney and necrotic tissues (white arrows) are detected by H\& E stain, scale bar is $200 \mu \mathrm{m}$ 

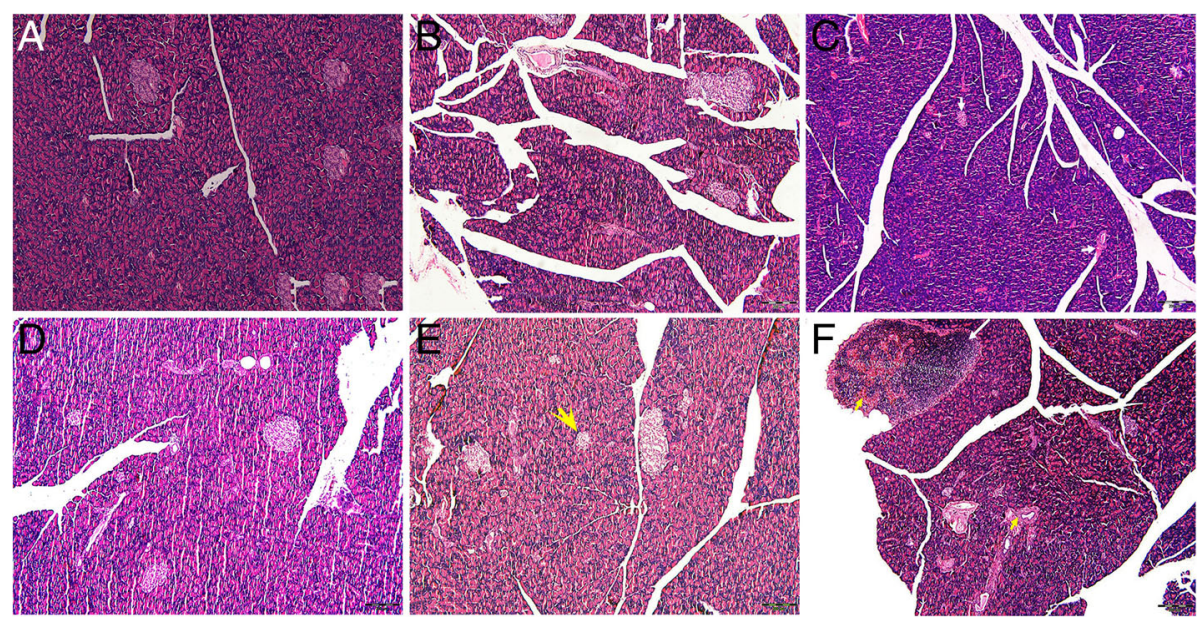

Fig. 3 Histological analysis of pancreatic tissue stained with hematoxylin and eosin. Upper panel (a-c) and lower panel (d-f) show female and male pancreas histological structure, respectively. a A representative micrograph of the pancreas of control females rat showing normal structure, normal beta cells shape and distribution. b Pancreatic micrograph section of rats fed 50\% GM food showing normal histology with some atrophied beta cells. c A micrograph of rats fed 100\% GM showing atrophied beta cells, hemolysis in different areas of the pancreas and amyloid bodies (white arrows). $\mathbf{d}$ A representative micrograph of the pancreas of control male group rat showing normal structure. e A section in the pancreas of group fed 50\% GM food showing normal histology and some atrophied beta cells (yellow arrow). $\mathbf{f}$ Pancreatic section of group fed 100\% GM showing amyloidosis (yellow star), neutrophil infiltration (long white arrow), and non-malignant pancreatic fibrosis (yellow arrows). It seems like an acute pancreatitis, which is associated by hypokalemia as reported by biochemical tests. Scale bar is $200 \mu \mathrm{m}$

observed histopathological changes in the current study were similar to other findings previously reported (Brasil et al., 2009).

Microscopic analysis of mammary tissue sections showed a thickened, more prominent stromal/ECM layer around those ducts distant from lymph node region in the $100 \%$ GM soybean group, associated with signs of acini formation, though the animals were not pregnant and had passed puberty phase (Lucas et al., 2007; Rudmann et al., 2005), whereas in low-dose treatment, the thickening was not evident and the periductal stroma was comparable to control ducts.

Scientific evidence indicated that glyphosate residues might accumulate in glyphosate-tolerant soybean (Bøhn et al., 2014). Our preliminary results revealed that no accumulation of glyphosate has been detected in the
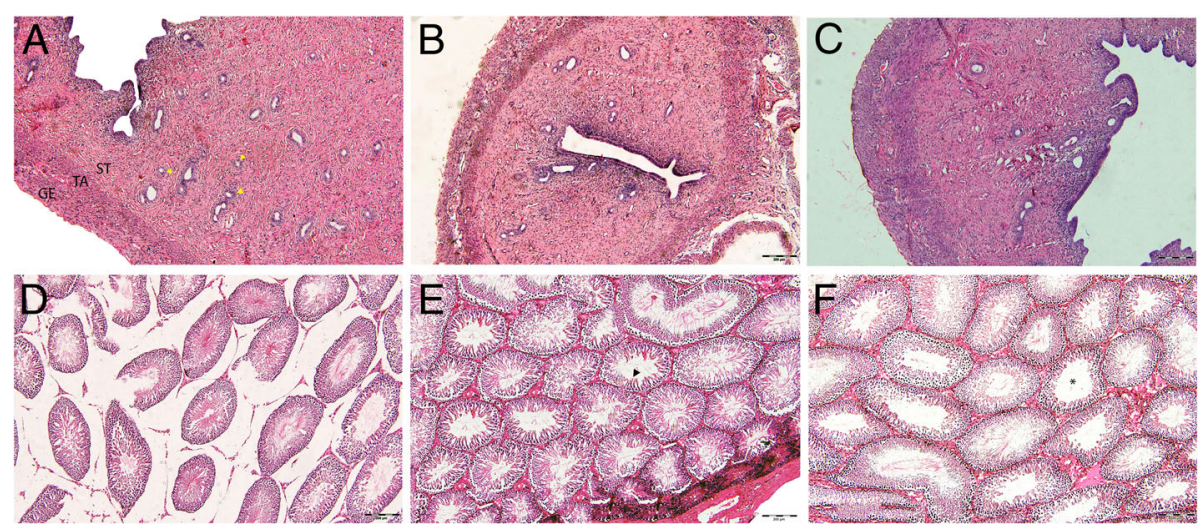

Fig. 4 Representative photomicrographs of gonadal structures of the experimental group. a-c Micrographs represents the testicular structure of a control group showing a normal histological appearance of tubules seminiferi; rats fed $50 \%$ GM food; $\mathbf{b}$ showing atrophy of seminiferous tubular, thinning of the tubule wall due to reduction in germ cells that make up tubular wall, the absence of spermatozoa in some tubule lumen (Black arrowhead) and $\mathbf{c}$ testis of 100\% GM soybean meal group showing seminiferous tubule dilation is characterized by increased luminal diameter of the seminiferous tubules (black star). $\mathbf{d}$-f $\mathbf{f}$ Micrographs represents the ovarian structure of $\mathbf{d}$ control group showing a normal histology displaying from outside toward inside the germinal epithelium (GE), tunica albuginea (TA), stroma (ST), and many of the primordial follicles (yellow arrowhead); female rats fed $50 \%$ and $100 \%$ GM food (e) and (f) respectively, showing normal histology and lesser number of primary and secondary follicles. H \& E stain, scale bar is $200 \mu \mathrm{m}$ 


\section{Control}

$50 \%$ GM soybean meal

$100 \%$ GM soybean meal
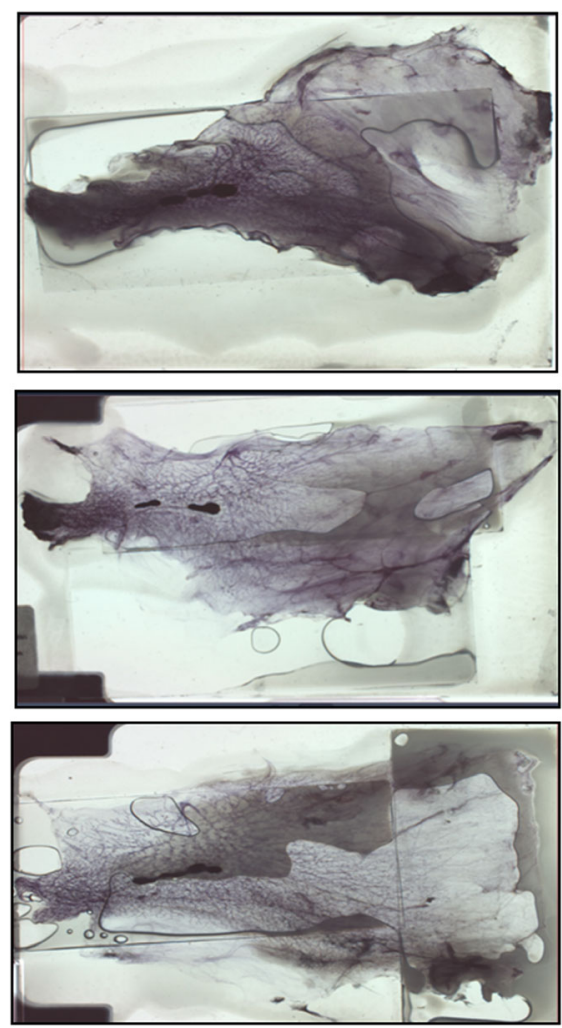

Fig. 5 Whole mount preparations for the inguinal mammary glands of female Wistar rats showing morphological changes and increase in the branches of mammary ducts fed by 50\% GM soybean and higher increase in branches of mammary ducts fed by $100 \%$ GM soybean

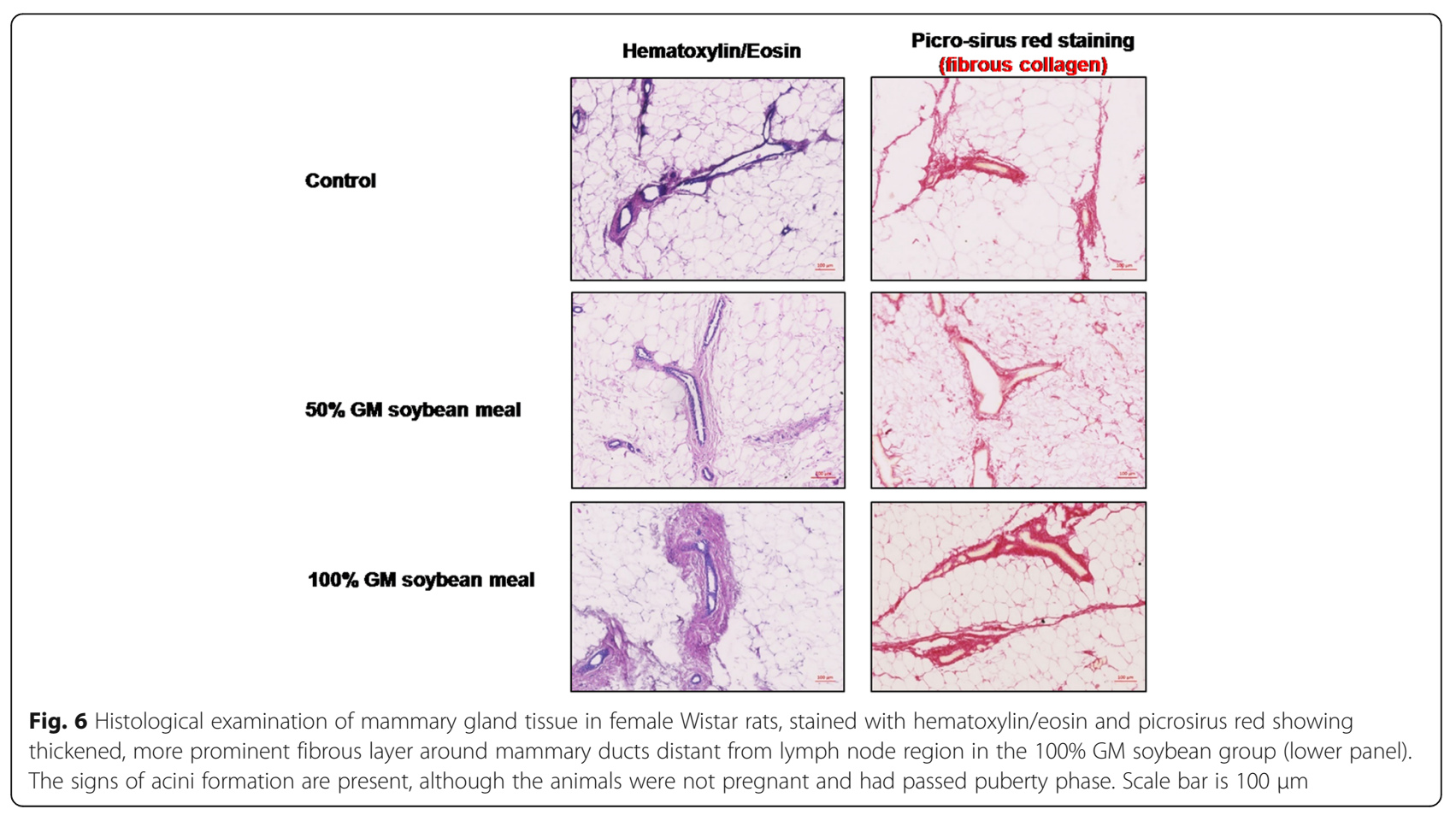


examined small intestine of the albino rat fed 100\% GM soybean meal (data not shown). Meanwhile, it is worth to mention one of the limitations of this study that we did not measure glyphosate level in other organs or body fluids.

The observed histopathological alterations and blood biochemical changes in our study may be related to consumption of GM soybean diet. The mechanisms responsible for this change are still unknown and further studies essentially required. Also, the obtained results indicate that necessity to revise the safety standards of consumption of diets containing glyphosate tolerant (RUR) GM soybean.

\section{Conclusion}

Genetically modified Roundup Ready food represents rigorous cultivation in the entire world with enormous potential benefits. We found distinct physiological, biochemical, and histological changes induced upon its feeding to the experimental animals for 18 weeks. The obtained results indicate the necessity to carefully revise the modern safety standards of consumption of diets containing GM soybean. Moreover, we should develop modernized safety testing, applicable regulation, effective policies, and food labelling.

\section{Additional files}

Additional file 1: Figure S1. Agarose gel electrophoresis of PCR-based detection of GM soybean with P-S35 primers (195 bp). Lane 1: a $100 \mathrm{bp}$ DNA ladder, lane 2: positive control (GM soybean meal) and lane 3: GM soybean sample (left hand). Agarose gel electrophoresis of PCR-based detection of GM soybean with EPSPS_RUR primers (172 bp). Figure S2. Lane 1: a 100 bp DNA ladder, lane 2: GM soybean meal sample, lane 3: non-GM soybean meal sample, and lane 4: negative control (non-GM soybean meal) showed on right hand. (DOCX $178 \mathrm{~kb}$ )

Additional file 2: Table S1. Chemical composition of non-GM soybean and GM soybean meals. Table S2. Amino acids content of non-GM soybean and GM soybean meals. Table S3. Fatty acid contentof non-GM soybean and GM soybean meal (as a relative percentage of total free fatty acid). (DOCX $16 \mathrm{~kb})$

\section{Abbreviations}

ALP: Alkaline phosphatase; ALT: Alanine aminotransferase; AST: Aspartate aminotransferase; $\mathrm{CHO}$ : Cholesterol; FAO: Food and Agriculture Organization of the United Nations; GM: Genetically modified; H\&E: Hematoxylin and eosin; HB: Hemoglobin; HCT: Hematocrit; Ht: Herbicide tolerance;

LDH: Lactate dehydrogenase; RBCs: Red blood cells; RUR: Roundup Ready; TG: Triglycerides; WBCs: White blood cells

\section{Acknowledgments}

We thank Dr. Atef Abdel Monem for statistical advice and help and Dr. Sameh Abou-Beih for his valuable inputs.

\section{Authors' contributions}

MIE, MAE, MMM, and MSE were responsible for suggesting, planning, designing the study, and writing the manuscript and MSE was major in writing the manuscript. MIE performed experiments and the supervision of the work was performed by MSE. AMI was responsible for examination and writing report of examination for mammary gland. AAE was responsible for histopathological examination and writing reports of examination for vital organs. All authors cooperate in revising the manuscript, read, and approved the final manuscript.

\section{Funding}

Not applicable.

Availability of data and materials

All data are available upon request.

Ethics approval and consent to participate

The experimental work was carried out at RCFF, in accordance with the national guidelines for care and use of laboratory animals.

\section{Consent for publication}

Not applicable.

\section{Competing interests}

The authors declare that they have no competing interests.

\section{Author details}

${ }^{1}$ Regional Center for Food \& Feed (RCFF), 9 El Gamaa Street, Giza, Egypt. ${ }^{2}$ Department of Zoology, Faculty of Science, Cairo University, Giza, Egypt.

${ }^{3}$ Department of Zoology, Faculty of Science, Aswan University, Aswan, Egypt.

Received: 28 January 2019 Accepted: 30 May 2019

Published online: 18 July 2019

\section{References}

Alexander, T., Reuter, T., Aulrich, K., Sharma, R., Okine, E. K., Dixon, W., \& McAllister, T. A. (2007). A review of the detection and fate of novel plant molecules derived from biotechnology in livestock production. Animal Feed Science and Technology, 133(1-2), 31-62.

AOAC (2012). Official methods of analysis of AOAC international. Gaithersburg: Assoc. of Official Analytical Chemists International.

Bancroft, J.D., \& Gamble M. (2008). Theory and practice of histological techniques. 6th Ed. Churchill Livingstone, Elsevier. p. 126-127.

Bøhn, T., Cuhra, M., Traavik, T., Sanden, M., Fagan, J., \& Primicerio, R. (2014). Compositional differences in soybeans on the market: Glyphosate accumulates in Roundup Ready GM soybeans. Food Chemistry, 153, 207-215.

Brandt, T., Mourier, A., Tain, L. S., Partridge, L., Larsson, N., \& Kühlbrandt, W. (2017). Changes of mitochondrial ultrastructure and function during ageing in mice and Drosophila. Elife, 6, e24662.

Brasil, F. B., Soares, L. L., Faria, T. S., Boaventura, G. T., Sampaio, F. J. B., \& Ramos, C. F. (2009). The impact of dietary organic and transgenic soy on the reproductive system of female adult rat. The Anatomical Record, 292(4), 587-594.

Chawla, L. S., \& Kellum, J. A. (2012). Biomarkers are transforming our understanding of AKI. Nature Reviews Nephrology, 8, 68.

Connors, L. H., Sam, F., Skinner, M., Salinaro, F., Sun, F., Ruberg, F. L., ... Seldin, D. C. (2016). Heart failure resulting from age-related cardiac amyloid disease associated with wild-type transthyretin: A prospective, observational cohort study. Circulation, 133(3), 282-290.

De Assis, S., Warri, A., Cruz, M. I., \& Hilakivi-Clarke, L. (2010). Changes in mammary gland morphology and breast cancer risk in rats. Journal of visualized experiments: JoVE(44), 1-4.

de Vendômois, J. S., Roullier, F., Cellier, D., \& Séralini, G.-E. (2009). A comparison of the effects of three GM corn varieties on mammalian health. International Journal of Biological Sciences, 5(7), 706-726.

Ding, L., Zhao, Y., Warren, C. L., Sullivan, R., Eliceiri, K. W., \& Shull, J. D. (2013). Association of cellular and molecular responses in the rat mammary gland to 17ß-estradiol with susceptibility to mammary cancer. BMC Cancer, 13(1), 573.

Domingo, J. L. (2016). Safety assessment of GM plants: An updated review of the scientific literature. Food and Chemical Toxicology, 95, 12-18.

El-Shamei, Z., Gab-Alla, A., Shatta, A., Moussa, E., \& Rayan, A. (2012). Histopathological changes in some organs of male rats fed on genetically modified corn (Ajeeb YG). Journal of American Science, 8(10), 684-696.

Ermakova, I. (2007). Experimental Evidence of GMO hazards. In Presentation at Scientists for a GM Free Europe, EU Parliament, Brussels.

Haryu, Y., Taguchi, Y., Itakura, E., Mikami, O., Miura, K., Saeki, T., \& Nakajima, Y. (2009). Longterm biosafety assessment of a genetically modified (GM) plant: The genetically modified (GM) insect-resistant Bt11 corn does not affect the 
performance of multi-generations or life span of mice. The Open Plant Science Journal, 3(1), 49-53.

He, X., de Brum, P. A., Chukwudebe, A., Privalle, L., Reed, A., Wang, Y., ... Huang, K. (2016). Rat and poultry feeding studies with soybean meal produced from imidazolinone-tolerant (CV127) soybeans. Food and Chemical Toxicology, 88, 48-56.

Keese, P. (2008). Risks from GMOs due to horizontal gene transfer. Environmental Biosafety Research, 7(3), 123-149.

Limdi, J. K., \& Hyde, G. M. (2003). Evaluation of abnormal liver function tests. Postgraduate Medical Journal, 79(932), 307-312.

Lucas, J. N., Rudmann, D. G., Credille, K. M., Irizarry, A. R., Peter, A., \& Snyder, P. W. (2007). The rat mammary gland: Morphologic changes as an indicator of systemic hormonal perturbations induced by xenobiotics. Toxicologic Pathology, 35(2), 199-207.

Malatesta, M., Boraldi, F., Annovi, G., Baldelli, B., Battistelli, S., Biggiogera, M., \& Quaglino, D. (2008). A long-term study on female mice fed on a genetically modified soybean: Effects on liver ageing. Histochemistry and cell biology, 130 967-977.

Malatesta, M., Caporaloni, C., Gavaudan, S., Rocchi, M., Serafini, S., Tiberi, C.\& Gazzanelli, G. (2002). Ultrastructural Morphometrical and Immunocytochemical Analyses of Hepatocyte Nuclei from Mice Fed on Genetically Modified Soybean. Cell structure and function, 27: 173-180.

Malatesta, M., Caporaloni, C., Rossi, L., Battistelli, S., Rocchi, M. B. L., Tonucci, F., \& Gazzanelli, G. (2002). Ultrastructural analysis of pancreatic acinar cells from mice fed on genetically modified soybean. Journal of Anatomy, 201(5), 409415.

Milani, P., Basset, M., Russo, F., Foli, A., Palladini, G., \& Merlini, G. (2017). The lung in amyloidosis. European Respiratory Review, 26(145), 170046.

Millstone, E., Brunner, E., \& Mayer, S. (1999). Beyond 'substantial equivalence'. Nature, 401(6753), 525.

Mohamad, M., Mitchell, S. J., Wu, L. E., White, M. Y., Cordwell, S. J., Mach, J., ... Cogger, V. C. (2016). Ultrastructure of the liver microcirculation influences hepatic and systemic insulin activity and provides a mechanism for agerelated insulin resistance. Aging Cell, 15(4), 706-715.

Nowicki, P, Aramyan, L, Baltussen, W, Dvortsin, L, Jongeneel, R, Domínguez, IP, . . Miller, D (2010). Study on the implications of asynchronous GMO approvals for EU imports of animal feed products, LEl, part of Wageningen UR.

Oraby, H., Kandil, M., Shaffie, N., \& Ghaly, I. (2015). Biological impact of feeding rats with a genetically modified-based diet. Turkish Journal of Biology, 39(2), 265-275.

Pierozan, C. R., Agostini, P. S., Gasa, J., Novais, A. K., Dias, C. P., Santos, R. S. K., Pereira Jr, M., Nagi, J.G., Alves, J. B. \& Silva, C. A. (2016). Factors affecting the daily feed intake and feed conversion ratio of pigs in grow-finishing units: the case of a company. Porcine Health Manag 2: 7.

Qi, X., He, X., Luo, Y., Li, S., Zou, S., Cao, S., ... Huang, K. (2012). Subchronic feeding study of stacked trait genetically-modified soybean (3Ø5423× 40-3-2) in Sprague-Dawley rats. Food and Chemical Toxicology, 50(9), 3256-3263.

Raffaella, T., Serena, C., Isabella, C. M., Vincenzo, P., \& Federico, I. (2011). Genetically modified soybean in animal nutrition. Soybean-genetics and novel techniques for yield enhancement. Dora krezhova, Intechopen. https://doi.org/10.5772/1 7594.

Reeves, P., Nielsen, F. H., \& Fahey, G. C. (1993). AlN-93 purified diets of laboratory rodents: Final report of the American Institute of Nutrition ad hoc Writing Committee on the reformulation of the AlN-76 rodent diet. The Journal of Nutrition, 123, 1939-1951.

Rudmann, D. G. Cohen, I. R. Robbins, M. R. Coutant, D. E. \& Henck, J. W. (2005). Androgen dependent mammary gland virilism in rats given the selective estrogen receptor modulator LY2066948 hydrochloride. Toxicologic Pathology, $33(6), 711-719$

Séralini, G.-E., Cellier, D., \& de Vendomois, J. S. (2007). New analysis of a rat feeding study with a genetically modified maize reveals signs of hepatorenal toxicity. Archives of Environmental Contamination and Toxicology, 52(4), 596-602.

Séralini, G.-E., Clair, E., Mesnage, R., Gress, S., Defarge, N., Malatesta, M., ... de Vendômois, J. S. (2014). Republished study: Long-term toxicity of a Roundup herbicide and a Roundup-tolerant genetically modified maize. Environmental Sciences Europe, 26(1), 14.

Teshima, R., Akiyama, H., Okunuki, H., Sakushima, J.-i., Goda, Y., Onodera, H., ... Toyoda, M. (2000). Effect of GM and Non-GM soybeans on the immune system of BN rats and B10A mice. J Food Hyg Soc Jpn, 41, 188-193.

Unnevehr, L., \& Grace, D. (2013). Aflatoxins: Finding solutions for improved food safety. International Food Policy Research Institiute, Washington
Wong, A. Y. T., \& Chan, A. W. K. (2016). Genetically modified foods in China and the United States: A primer of regulation and intellectual property protection. Food Science and Human Wellness, 5(3), 124-140.

Zdziarski, I., Edwards, J., Carman, J., \& Haynes, J. (2014). GM crops and the rat digestive tract: A critical review. Environment International, 73, 423-433.

\section{Publisher's Note}

Springer Nature remains neutral with regard to jurisdictional claims in published maps and institutional affiliations.

\section{Submit your manuscript to a SpringerOpen ${ }^{\circ}$ journal and benefit from:}

- Convenient online submission

- Rigorous peer review

- Open access: articles freely available online

- High visibility within the field

- Retaining the copyright to your article

Submit your next manuscript at $\boldsymbol{\nabla}$ springeropen.com 